\title{
Morphology of the Diaphragm Muscle in Southern Tamandua (Tamandua tetradactyla) and its Importance in Cases of Traumatic Hernia
}

\author{
ÉRICA F.S. AZEVEDO, DANIELA R. COSTA E SILVA, TAMIRES V.S. NATIVIDADE, \\ ELANE G. GIESE, ANA RITA DE LIMA, PAOLA C. SOARES and ÉRIKA BRANCO \\ Faculdade de Medicina Veterinária, Universidade Federal Rural da Amazônia/UFRA, Instituto da Saúde e \\ Produção Animal, Avenida Presidente Tancredo Neves, 2501, Montese, 66077-530 Belém, PA, Brazil
}

Manuscript received on August 31, 2017; accepted for publication on December 20, 2017

\begin{abstract}
The wall of the diaphragm can be affected by changes caused by physical trauma, allowing the passage of viscera between the abdominal cavity and thoracic cavity, thus reducing the space for pulmonary expansion, leading to the formation of hernia and possible death. Thus, we aimed to characterize, size and determine the topography of the diaphragmatic muscle in the Southern Tamandua, since clinical and surgical activities in wild animals have become a reality more and more present in veterinary medicine. We used six adult animals, $\mathrm{x}$-rayed and dissected, followed by collection of fragments of muscular portions for histological analysis. Initially we observed that the animals presented 17 thoracic vertebrae, 3 lumbar vertebrae and 5 sacral vertebrae. The diaphragm was conformed by three segments: sternal, costal and right and left diaphragm pillar, with presence of tendinous centre that housed the passage of the caudal vena cava, called foramen of the caudal vena cava. Dorsally to the tendinous centre, already in the muscle portion, we located the esophageal and aortic hiatus. These findings, as well as the microscopic, were equivalent to that found in the general literature also, corroborating with descriptions already carried out in other mammals' diaphragms.
\end{abstract}

Key words: diaphragmatic hernia, morphology, Tamandua tetradactyla, Xenarthra.

\section{INTRODUCTION}

The diaphragmis a muscularorgan with fundamental importance in the process of respiration, which is a complex system, as the contraction of the respiratory muscles for ventilation of the lungs is a continuous requirement. Found only in mammals, the diaphragm separates the thoracic from the abdominal cavity (Moreira et al. 2007, Feldman

Correspondence to: Érika Branco

E-mail: ebranco.ufra@gmail.com
2006 and 2011), with concave surface, facing the thoracic cavity, and convex toward the abdominal cavity, thus obtaining dome format (Getty 1986, Dyce et al. 2010).

During inspiration, crucial phase of the respiratory cycle, the format of the thoracic cavity increases to allow the entry of air into the lungs, due especially to the diaphragm, since the process is active; and then, however, not less important, also due to the movement of the costochondral joints. That way, when the contraction of the diaphragm 
occurs, the central part moves caudally, facilitating the entry of air into the thoracic when reducing the curvature of the diaphragmatic dome (Lessa et al. 2012).

The diaphragm is important not only for the respiratory process, but also in defecation (from the contraction of the large intestine); in aiding the expulsion of the fetus during labor; in support of the body and even the digestive process, once the diaphragm helps in constricting the cardia, preventing acid reflux (Didio et al. 2002).

Clinically, the diaphragm has great importance when thinking about situations of hernias, which, when caused by physical trauma is a condition that afflicts veterinarians, especially concerning hit-andrun situations, where the index is significant, and usually occurs the dislocation of organs from the abdominal cavity to the thoracic cavity, reducing thus the room for pulmonary expansion, leading to death (Fighera et al. 2008). This condition becomes even more worrying after the recent findings showing that some longitudinal muscle fibers of the esophagus leave the esophagus and merge into the crural diaphragm (Zifan et al. 2017).

Trauma near the diaphragm, as well as local biomechanical alteration, can induce respiratory muscle dysfunction (RMD) and reduction of the maximum respiratory pressure, resulting from abdominal surgery. With that, pulmonary complications may develop and worsen the animal situation. In this way, the weakness of the respiratory muscles and diaphragmatic dysfunction may be related to postoperative pulmonary complications, reducing respiratory functions and the expectoration ability (Martins 2007).

Being of anatomical nature, the surgical treatment is the only one indicated for alterations in the diaphragmatic ruptures (Hage and Iwasaki 2001). Clinical signs are essential for an efficient completion of the diagnosis of diaphragmatic hernias which include: respiratory distress, cyanosis and shock, although it can also be asymptomatic. In this way, the diagnosis is a result not only of the history and clinical signs, but also of the radiographic examination. In some cases, contrasted ultrasound and x-ray may be necessary to confirm the investigation (Ford and Mazzaferro 2007).

When it comes to clinical/surgical care routine of domestic animals, the diaphragmatic trauma is a common reality, especially in dogs and cats, however, with the increasingly participation of the veterinarian in the clinic and surgery of wild animals, this condition in several species becomes a challenging factor in view of the process of urbanization and proximity of wildlife to major centres. In this context, we highlight the Southern Tamandua, mammal belonging to the Xenarthra superorder which, despite having nocturnal habits, it is not uncommon to be seen during the day on roads (Fonseca et al. 1996, Machado and Santos 2008, Rodarte 2010). Furthermore, information on the anatomy of Xenarthra revealed important aspects of various organs and systems, adding a great biological value to the representatives to the representatives of this group, contributing not only to the preservation of these animals, but also to the discovery of new experimental models (Iglesias et al. 2017).

On the exposed, associated with the scarce literary on the morphophysiology of the diaphragm in a number of wild species, in particular the species studied here, we aimed to characterize, size and determine the topography of the diaphragmatic muscle in Southern Tamandua, considering that clinical and surgical activities in wild animals have become a reality more and more present in the veterinarian's routine.

\section{MATERIALS AND METHODS}

We used six adult animals (one male and five females), from Bauxite Paragominas Mine in Pará, under the authorisation of SEMA-PA in 455/2009 
and 522/2009, which were road killed, frozen and sent to the Laboratory of Morphological Animal Research - LaPMA, from the Federal Rural University of Amazonia - UFRA.

The animals were thawed and $\mathrm{x}$-rayed at the Veterinary Hospital of UFRA. The x-rays of the thorax and abdomen were performed with the corpses in ventral and lateral decubitus, using dorsoventral and left latero lateral projections, respectively. The $\mathrm{x}$-rays were performed using the Intecal $\AA$ X-ray unit, model CR-7, $100 \mathrm{kV}$ power, maintaining a focus film distance of $100 \mathrm{~cm}, 100$ $\mathrm{mA}$ and time of 0.4 seconds. For the exams we used exposure factors on the order of $55 \mathrm{kVs}$ and $2.5 \mathrm{~m}$. As for the lateral radiographs, and $60 \mathrm{kVs}$ for the dorsoventral radiographs. The results have been documented for further analysis of the radiographic findings.

Then, the bodies were dissected with basic surgical instruments by an incision in the linea alba, from the xiphoid cartilage until near the mons pubis, with posterior divulsion of the skin and subcutaneous tissue and removal or divulsion of some organs of the abdominal cavity, aiming to amplify the field of vision of the caudal region of the diaphragm.

After opening the cavity mentioned above, we withdrew the diaphragm muscle by cutting near the regions of lumbar, costal and sternal insertions, in order to preserve the anatomical format. Then, using a digital caliper, we measured height and width, starting from two equidistant points (dorsoventral and latero lateral). Later, we photo documented, fixated in formaldehyde (10\%) and store.

We collected fragments of the muscular and central portions of the diaphragm for light microscopy, and stored these fragments in formaldehyde $4 \%$. After 24 hours, the tissues were embedded in paraffin, sectioned into $5 \mu \mathrm{m}$ in thickness in a Zeiss Hyrax M25 microtome and stained with hematoxylin and eosin. The images were obtained with a Leica DM 2500 microscope and a Leica DFC 310FX camera.

All nomenclature adopted was based in Nomina Anatomica Veterinaria (International committee on veterinary gross anatomical nomenclature, 2012).

\section{RESULTS}

All animals studied showed 17 thoracic vertebrae, 3 lumbar vertebrae and 5 sacral vertebrae, which contributes to the format of the abdominal cavity. We can note on the radiograph (Figure 1) that the diaphragm was inserted into the dorsal plan, between T11 and T12. Ventrally, the diaphragm interposed at the xiphoid cartilage between the $11^{\text {th }}$ and $12^{\text {th }}$ ribs, and cranially revealed a dome format.

\section{MACROSCOPICALLY}

From the dissection carried out, it was possible to evaluate the topography and biometry of the organ, as well as the average and standard deviation values, arranged in Table I. We also evaluated the architecture of the diaphragm, confirming the dome format, showing proper conformation of scoop for the abdomen (Figure 2a) and convexity to the thorax.

The structural conformation of the diaphragm revealed a central region of fibrous connective tissue, formed by the intersection of the median tendons of the periferic digastric muscles, called tendinous centre, occupying the central portion of the diaphragm, highlighting the waypoint of the caudal vena cava, called foramen of the caudal vena cava (Figure $2 b$ ).

The muscular portion, located in the peripheral region of the diaphragm, appeared to be thicker when compared to the tendinous centre, a particular feature that demonstrates resistance. In this portion we can see two openings, the first called esophageal hiatus and the second called aortic hiatus (Figure $2 b)$. 


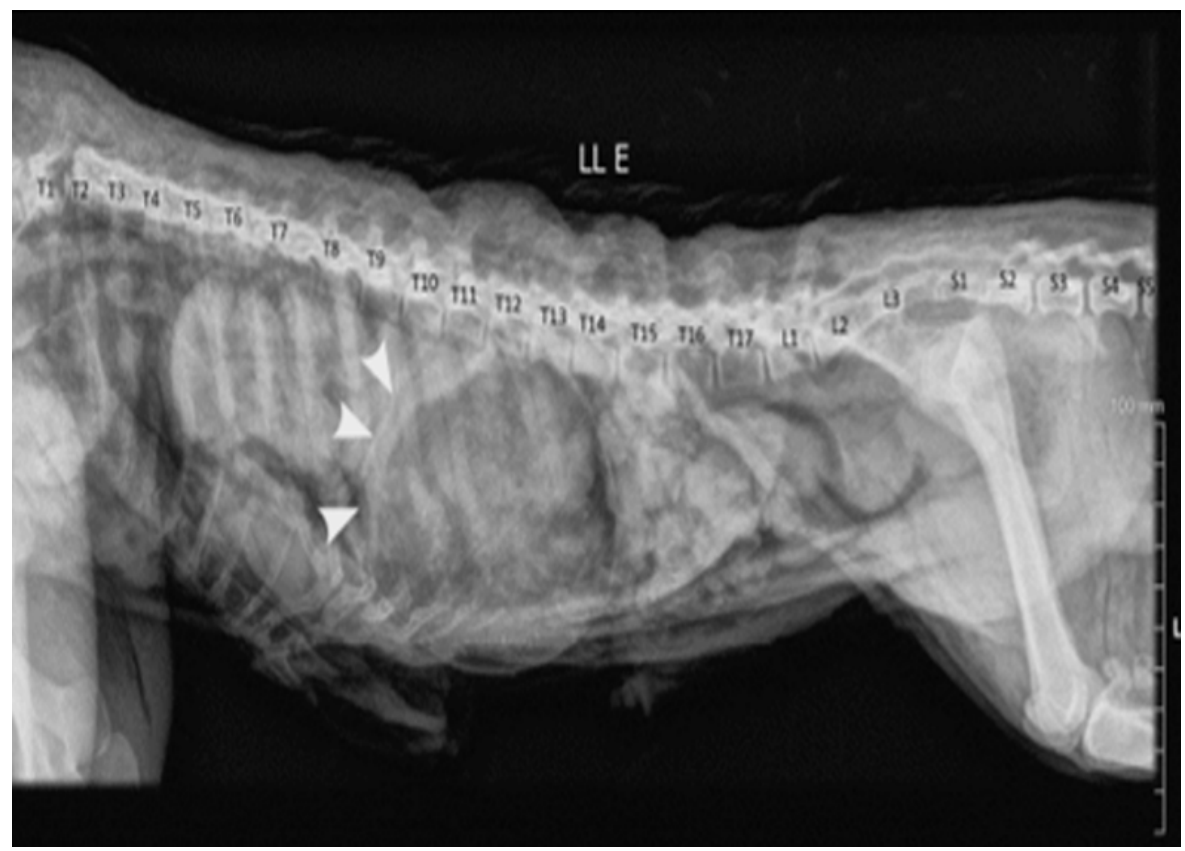

Figure 1 - Radiographic image in latero lateral projection of the thoracoabdominal region of the Southern Tamandua, demonstrating the diaphragmatic muscle insertion in T12, projecting parallel to the medial aspect of the $7^{\text {th }}$ to the $11^{\text {th }}$ pair of ribs, settling in the xiphoid region, constituting a dome format (arrow).

TABLE I

Biometric values of the diaphragm muscle of the Southern Tamandua.

\begin{tabular}{cccc}
\hline Animal & Height $(\mathrm{cm})$ & Width $(\mathrm{cm})$ & $\begin{array}{c}\text { Location } \\
\text { (ribs) }\end{array}$ \\
\hline $1(\mathrm{~F})$ & 15.1 & 15.5 & $13-17$ \\
$2(\mathrm{~F})$ & 15 & 14 & $12-16$ \\
$3(\mathrm{~F})$ & 14.2 & 12.27 & $10-18$ \\
$4(\mathrm{~F})$ & 15.4 & 17.6 & $09-14$ \\
$5(\mathrm{M})$ & 16.4 & 14.8 & $08-16$ \\
$6(\mathrm{~F})$ & 13.5 & 15.2 & $09-15$ \\
Average & 14.93 & 14.895 & ----- \\
Standard & 0.9122 & 1.6060 & ------ \\
Deviation & & & \\
\hline
\end{tabular}

F: Female; M: Male.

We also noticed a division on the conformation of this musculature that possessed an insertion in the tendinous centre, such as: the sternal part, cranially adhered to the xiphoid process of the sternum then; the coastal part, represented by the bundles that linked to the coastal cartilages and the corresponding ribs. The third part, more proximal to the tendinous centre, presented the diaphragm pillar, holding the diaphragm muscle (Figure 2b).

The diaphragm was innervated by the phrenic nerve, which distributed through the fleshy portion, and was inserted into the tendinous centre of the muscle. Caudally, the diaphragm presented itself to the lung and heart, being attached to the latter through the phrenicopericardial ligament (Figure 2c).

\section{MICROSCOPICALLY}

The histological analysis of the organ revealed the presence of groups of elongated and cylindrical cells, as well as cells that display multiple nucleus of peripheral location (Figure 3). The muscle fibers had transverse striations, an aspect that is due to the alternation of dark and light bands (Bands A and I, respectively). These findings are characteristic striated skeletal muscle cells.

The organ was coated by the epimysium, a structure formed by an extensive layer of 


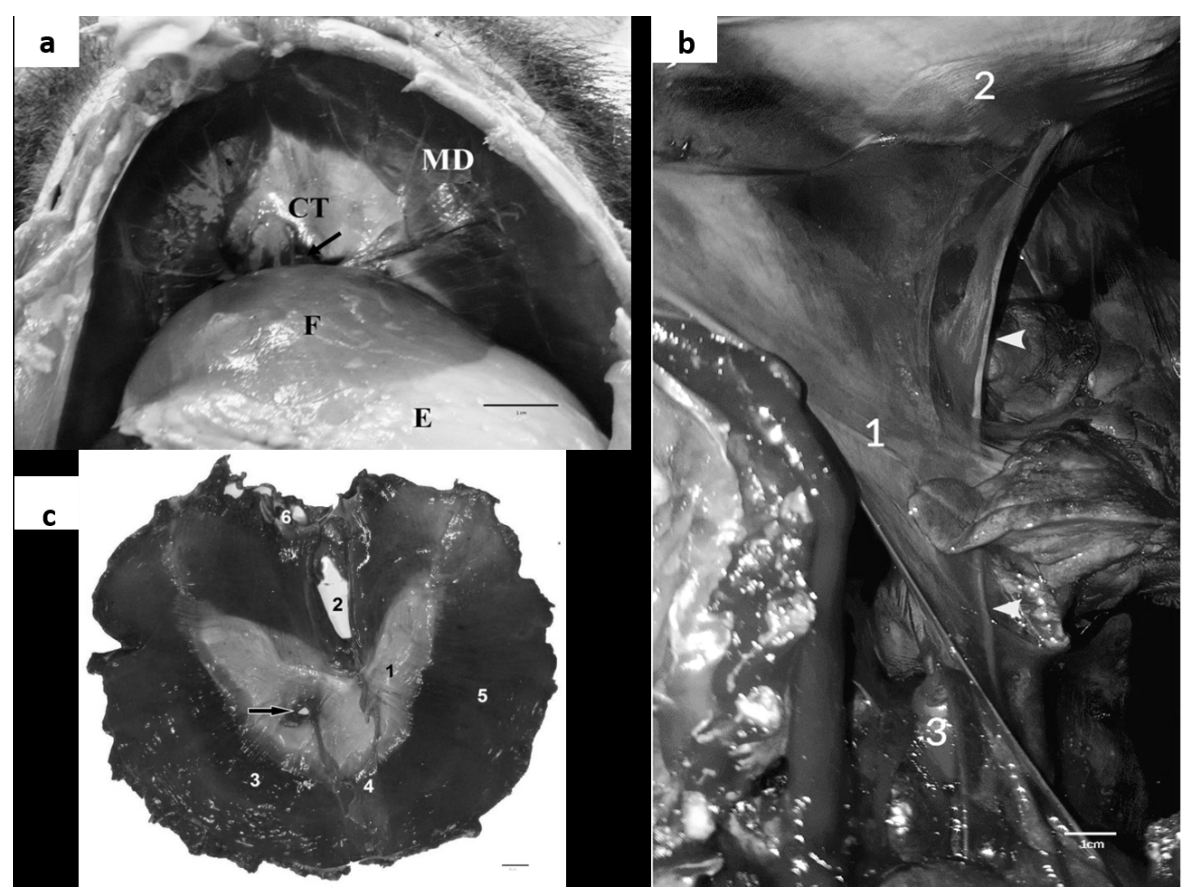

Figure 2 - Photomacrography of the diaphragm muscle of the Southern Tamandua (in situ). a: Caudal portion highlighting the tendinous centre (CT). We can note the concave formation of the muscle of the diaphragm (MD) and organs of the abdominal cavity, like the liver (F) and stomach (E). Next to the tendinous centre, we can observe the caudal vena cava crossing the foramen of the caudal vena cava (arrow). Scale bar: $1 \mathrm{~cm}$. b: Photomacrography of the diaphragm muscle of the Southern Tamandua (ex situ). Presence of the mediastinal pleura (1), diaphragm (2), aorta (3) and phrenic nerve (arrow). Scale bar: $1 \mathrm{~cm}$. c: Abdominal portion of the diaphragm muscle of the Southern Tamandua. Tendinous centre (1), esophageal hiatus (2), right coastal portion (3), sternal part (4) of the diaphragmatic dome, left costal portion (5), aortic hiatus (6), foramen of the caudal vena cava (arrow). Scale bar: $1 \mathrm{~cm}$.

connective and adipose tissues, which exhibited intense vascularization, as well as the presence of a nervous bundle with high caliber.

From the epimysium, we noticed tissue invaginations organized in septum, which covered, and consequently, separated the muscle bundles, forming the perimysium. Each cell, in turn, was covered by the endomysium, a structure constituted by the basal lamina of each muscle fiber, and reticular fibers.

\section{DISCUSSION}

The diaphragm is a unique and vital respiratory muscle that has been studied in several areas, such as: zoology, physiology, physics, medicine, comparative and experimental anatomy and philosophy (Lessa et al. 2016).

Topographically, the diaphragm of the Southern Tamandua resembled other domestic and wild species studied (Getty 1986, Popesko 1990, Evans and Lahunta 1994, Sayeed and Darling 2007, Dyce et al. 2010, Moore et al. 2010). However, when we observe the related literature regarding the diaphragm of wild animals, Helrigle et al. (2013) observed that, in Procyon cancrivorus, and Moore et al. (2007) on Callithrix jacchus, the diaphragm muscle skeletal fixation begins in the xiphoid process, moving laterally to the ventral edge of the costal cartilages, similar to the results found for the Southern Tamandua. 


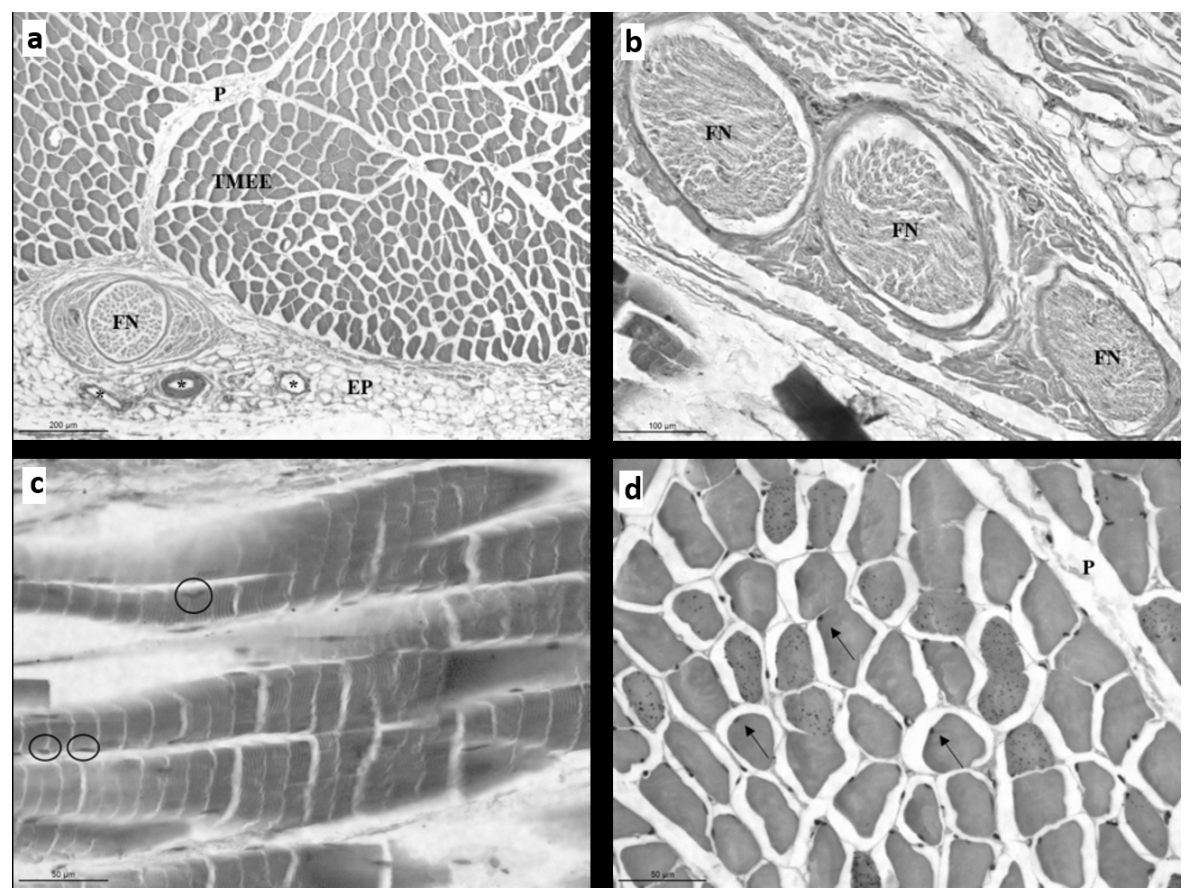

Figure 3 - Photomicroscopy of the diaphragm of Southern Tamandua. a: Overview of the organ composed by skeletal striated muscle tissue (TMEE) and covered by the epimysium (EP). Notice invaginations of connective tissue (P), portion of nervous bundle (FN) and vascularization (*). Gömöri trichrome stain. Scale bar $200 \mu \mathrm{m}$. b: nervous bundle (FN), composed of 3 nerve fibers. H\&E stain. Scale bar $100 \mu \mathrm{m}$. c: Myocytes in longitudinal cut. Notice the stratifications and peripheral nucleus (circles). H\&E stain. Scale bar $50 \mu \mathrm{m}$. d: Myocytes in transversal cut, covered by the endomysium (arrows). Gömöri trichrome stain. Scale bar $50 \mu \mathrm{m}$.

As described for domestic carnivores (Getty 1986, Popesko 1990, Evans and Lahunta 1994, Sayeed and Darling 2007, Dyce et al. 2010, Moore et al. 2010), in this study the diaphragm muscle was divided into three parts: lumbar, sternal and costal, and these had the tendinous centre transfixed by the caudal vena cava, aorta, thoracic duct, oesophagus and azygos vein.

The diaphragm muscle of the Southern Tamandua is a tendinous muscular splitter, which separates the thoracic and abdominal cavities, fundamental for the respiratory function and survival of the animal (Wynn et al. 2013). The tendinous centre is the region responsible for muscle contractile process, once it has the phrenic nerves (Helrigle et al. 1986). In carnivores, phrenic nerves branch off of the diaphragm muscle, for a single motor innervation, in which there is the complement of the sensory fibers by the intercostal nerves (Moreira et al. 2007), as noted in Southern Tamandua.

The tendinous centre of the Southern Tamandua revealed a "V" format, located on the transverse plane, common in most mammals (Getty 1986, Dyce et al. 2010), except in manatees (Trichechus manatus latirostris), in which the diaphragm presents fibers in the tendinous centre that are attached to bone epiphysis, and persist, producing two hemi-diaphragms, and taking the form of an "I" (Rommel and Reynolds 2000). Already in Guinea pigs (Cavia porcellus) and White-eared opossums (Didelphis albiventris), their tendinous centre have a format similar to the letter "U" (Cassel et al. 2001), which in your time 
are similar to our findings in Southern Tamandua. This condition differs from the findings of Evans (2001) in the dog, in which the tendinous centre is similar in format with the letter "Y".

As noted in non-human primates, in which the diaphragmatic muscle promotes the livelihood for the viscera during inspiration, depending on the stability of the lumbar paravertebral muscles (Bennati 2001), the abdominal wall of the Southern Tamandua promotes total stability of the diaphragm on effective contraction, since it has a discontinuous architecture of the muscle fibers, an important feature in synchronized muscle contraction (Lander et al. 2012).

About the location and anchoring of the diaphragm muscle of the Southern Tamandua, we observed variations of inserts between the $11^{\text {th }}$ to the $17^{\text {th }}$ pair of ribs, a result similar to the diaphragm study of other mammals (Gauthier and Padykula 1966), in which the positioning is since the bodies of the lumbar vertebrae, dispersing to the ribs. This condition affects directly the type of surgical approaches, in which the choice of technique is determined by the ability to find the side of the break and its chronicity, regarding thoracic adhesions. However, the most used are the midline laparotomy and the intercostal thoracotomy (Johnson 1993).

The anatomical features, such as the symmetry of the muscle fascicles, observed in the diaphragm of other small mammals are similar in laboratory animals (Pompeu et al. 1992, Amorim Júnior et al. 1993, Lessa et al. 2012). In the muscular portion, we verified the presence of symmetrical fascicles, which corresponds to the study using rabbits (Oryctolagus cuniculus) and common marmosets (Callithrix jacchus).

The tendinous centre is characterized by being a central membrane, composed of collagen fibers interwoven, similar to that described by Harrison (2005). However, it has a not-so-thin central aponeurosis, being resistant when compared to the other portions of the muscle. According to
Getty (1986) and Junqueira and Carneiro (2004), externally to the sarcolemma of the muscle, there is a thin layer of tissue called endomysium; and each fiber is surrounded by a lot of connective tissue forming the perimysium. The outermost layer, thin, that surrounds the muscle of the diaphragm, is called the epimysium. In the present study we also found such structures, especially the epimysium of the Southern Tamandua's diaphragm, which has a thick layer of connective and adipose tissue, giving greater resistance to cutting. This is considered to be an interesting histological finding interesting since, in other species studied previously, this turns to be a thinner layer. According to Beck et al. (2004), diaphragmatic coastal muscles suffer from break more frequently than the tendinous centre. The fact is that there is an increase of connective tissue within the muscle fiber, which Vandervoort (1998) explains to be the responsible for the rigidity and resistance to breakage in this region.

In goats, $58.9 \%$ of fibers are of type I, and $41.1 \%$ are of type II. In humans, more than $50 \%$ of these fibers are of type I (Ibebunjo 1993). The tendinous centre of the Southern Tamandua has greater amount of type I collagen fibers, which features the resistance to cutting, since this type of collagen is considered more resistant and is organized in greater quantity and in thicker bundles (Salonen et al. 1985), leading us to believe that this species has more resistance in its diaphragm when dealing with trauma and consequent hernias.

Hernias are diseases that can affect the diaphragm, being classified in two categories: congenital and acquired, being described in human beings as congenital (Bochdalek, Morgagni and hiatal), and the ones from traumatic nature, like the acquired diaphragmatic hernia (Skandalakis 2004). According to Mazzanti et al. (2001), the occurrence of diaphragmatic hernia in veterinary patients is relatively high, found mostly in small animals. The most common causes are trauma as a result of being hit on the road (Levine 1987, Hosgood 
1996, Burton and White 1997), representing 85\% of the cases of this type of trauma, against the 5 to $10 \%$ of the ones from congensital origin and the others, considered of unknown etiology (Warkany and Roth 1948, Wilson and Hayes 1986, Boudrieau 1993).

In hernias processes, the radiographic examination is vital to ratify the diagnosis and plan surgical intervention. This must be performed with the animal lying with the four members supported, or in the ventrodorsal position, with dorsoventral incidence of the rays (Punch et al. 1985). According to Birchard (2003), the radiographic aspect varies according to the size and location of the alteration of the diaphragm, and the amount and the type of viscera involved in the hernia. Diaphragmatic surface discontinuity, herniation of the gastrointestinal tract or other abdominal organs into the thorax cavity are the most evident radiographic signs.

In simple and recent cases of diaphragmatic hernia, the correction is done surgically by the approximation and suture of the margins. However, when it comes to congenital hernias, the diaphragmatic protrusion is very extensive or there is muscle shrinkage and fibrosis, hampering the immediate repositioning. The usual treatment may be impractical, having the need of alternative surgical procedures. Among these, we highlight the use of prosthesis and biological tissues (Shaffer 1964, Geever and Merendino 1952, Fayolle 1982), which makes more evident the need to know the morphology and topography of the diaphragm, in order to know how to conduct the case.

In dogs and cats, the traumatic diaphragmatic hernia is the most common among diaphragmatic hernias (Levine 1987, Johnson 1993), and falls, kicks and fights (Boudrieau and Muir 1987, Levine 1987, Hage and Iwasaki 2001), as well as car accidents, the causes of these changes (Wilson et al. 1971, Boudrieau and Muir 1987, Levine 1987). Based on this, the only treatment is still surgery, since the changes in the diaphragmatic ruptures are of anatomical nature. Surgical interventions mostly used in veterinary medicine are the midline laparotomy and the intercostal thoracotomy (Hage and Iwasaki 2001).

According to Skandalakis (2004), the diaphragm hernia caused by trauma is more common on the right side, with a portion of omentum, colon, stomach, and may result in the inability of the lung to inflate as well as a reduction in the functional residual capacity (Wilson et al. 1971). However, Bastos et al. (2008) contradict the author mentioned above, claiming that injury of the diaphragm on the right side are usually protected by the liver, and has less risk of hernia or injury of the gastrointestinal tract.

\section{CONCLUSIONS}

The anatomical study of the diaphragm in different species is fundamental not only to enlighten morphological records, but it also aims to add information on the management of wild species and assist in surgical procedures.

The anatomical structures analysed in the diaphragm of the Southern Tamandua allowed us to conclude that there are three openings in the muscle (foramen of the caudal vena cava, aortic and esophageal hiatus) that corroborates with descriptions already carried out for other mammals.

The anatomical study of the diaphragm of different species is of extreme importance to the descriptions of cases of hernias, a common disease, with reports in domestic animals such as dogs, cats and horses.

Since acquired diaphragmatic hernias caused by trauma, in particular hit, require surgical correction, the search for care and attention in a short period of time becomes crucial to determine the survival rate of the animal. With the Southern Tamandua this would be no different, since these animals present several amendments and even death due to hit and run accidents, being the fourth most registered species in roadkills (CBEE 2017). 
Due to the structural similarity of the diaphragm of the Southern Tamandua when compared with other mammals reported in the literature, we can note the attention in clinical and/or surgical approaches. However, the wide extensions of connective and fat tissues in great proportions by the epimysium, as well as the presence of type I collagen in the tendinous centre, can justify a greater resistance of this region facing trauma, and this fact can be a differential between life and death.

\section{REFERENCES}

AMORIM JÚNIOR AA, BITTENCOURT AM AND AMORIM MJAAL. 1993. Ramificação e distribuição dos nervos frênicos no diafragma de sagui (Callithrix jacchus). Rev Bras Cienc Morfol 10(2): 108-113.

BASTOS R, BAISDEN CE, HARKER L AND CALHOON JH. 2008. Penetrating Thoracic Trauma. Semin Thorac Cardiovasc Surg 20: 19-25.

BECK CAC, PIPPI NL, BRUN MV, CONTESINI EA, CUNHA AF, BONFADA RSATB, FILHO APFS, GOMES K AND COLOMÉ LM. 2004. Toracoscopia nas hérnias diafragmáticas: estudo experimental em cães. Cienc Rural 34(6): 1857-1863.

BENATTI AT. 2001. Equilíbrio tóraco-abdominal integrada à respiração e à postura. Arq Ciencias Saude 5: 87-92.

BIRCHARD SJ AND SHERDING RG. 2003. Manual Saunders: clínica de pequenos animais. São Paulo: Roca, p. 664- 674.

BOUDRIEAU R. 1993. Pathophysiology of traumatic diaphragmatic hernia. In: Bojrab MJ (Ed), Mechanisms of Disease, Philadelphia: Lea \& Febiger, 103 p.

BOUDRIEAU RJ AND MUIR WW. 1987. Pathophysiology of Traumatic Diaphragmatic Hernia in Dogs. Compendium of Continued Education for the Practice of Veterinary 9(4): 379-385.

BURTON C AND WHITE R. 1997. Surgical approach to a ruptured diaphragm in the cat. In Pract 19: 298-305.

CASSEL FD, SOARES JC, TORREJAIS MM AND MATHEUS SMM. 2001. Anatomical study of the diaphragm of the opossum (Didelphis albiventris). Anat Histol Embryol 31: 132-138.

CBEE - CENTRO BRASILEIRO DE ESTUDOS EM ECOLOGIA DE ESTRADAS. 2017. Disponível em: http://cbee.ufla.br/portal/sistema_urubu/urubu-info.php. Acesso em: 23 de agosto de 2017.

DIDIO LJA. 2002. Tratado de Anatomia Sistêmica Aplicada: princípios básicos e sistêmicos, esquelético, articular e muscular, $2^{\mathrm{a}}$ ed., Atheneu, São Paulo.
DYCE KM, SACK WO AND WESING CJG. 2010. Tratado de anatomia veterinária, $2^{\mathrm{a}}$ ed., Rio de Janeiro - Guanabara Koogan, 820 p.

EVANS HE. 2001. Abdome, pelve e membro pélvico. In: Evans HE and Delahunta A (Eds), Guia para dissecção do cão, $5^{\text {a }}$ ed., Rio de Janeiro: Guanabara Koogan, $125 \mathrm{p}$.

EVANS HE AND LAHUNTA A. 1994. Guia para a dissecção do cão, $3^{\text {a }}$ ed., Rio de Janeiro - Guanabara Koogan, p. 105109.

FAYOLLE P. 1982. Cure chirurgicale d'une hernie diaphragmatique chez le chien par mise en place d'une prothése synthétique. Rev Méd Vet 133: 179-181.

FELDMAN JL. 2011. Chapter 14 - Looking forward to breathing. Prog Brain Res 188: 213-218.

FELDMAN JL AND DEL NEGRO CA. 2006. Looking for inspiration: new perspectives on respiratory rhythm. Nat Rev Neurosci 7: 232-242.

FIGHERA RA, SILVA MC, SOUZA TM, BRUM JS, KPMMERS CD, GRAÇA DL, IRIGOVEN LF AND BARROS CSL. 2008. Aspectos patológicos de 155 casos fatais de cães atropelados por veículos automotivos. Cienc Rural 38(5): 1375-1380.

FONSECA GAB, HERRMAN G AND LEITE YLR. 1996 . Lista anotada dos mamíferos do Brasil. Occasional Papers in Conservation Biology 4: 1-38.

FORD RB AND MAZZAFERRO EM. 2007. Manual de procedimentos veterinários e tratamento emergencial, $8^{\mathrm{a}}$ ed., São Paulo: Roca, 253 p.

GADELHA PS, COSTA AGD, COSTA HAD AND DANTAS RL. 2008. Malformações do diafragma e tubo digestivo: aspectos diagnósticos. Femina 36(2): 121-125.

GAUTHIER GF AND PADYKULA HA. 1966. Cytological studies of fiber type in skeletal muscle. A comparative study of mammalian diaphragm. J Cell Biol 28: 333-354.

GETTY R. 1986. Anatomia dos Animais Domésticos, Vol. 1, $5^{\mathrm{a}}$ ed., Rio de Janeiro: Guanabara Koogan, 1134 p.

HAGE MCFNS AND IWASAKI M. 2001. Contribuição ao estudo radiográfico das rupturas diafragmáticas em cães e gatos. Clinic Vet (35): 36-50.

HARRISON GR. 2005. The anatomy and physiology of the diaphragm, In: Braunwald E, Hauser SL, Longo DL, Fauci AS, Kasper DL, Wiener CM, Nivatpumin PJ, Brown CD and Hemnes AR (Eds), Princípios de Medicina Interna, $16^{\mathrm{a}}$ ed., McGraw-Hill, Rio de Janeiro, p. 45-58.

HELRIGLE C, PARANAIIBA JFFS AND PEREIRA KF. 1986. Structural aspects of the diaphragm of crab eating raccoon (Procyon cancrivorus). Rev Cient Eletrônica Med Vet 20: 1-14.

HOSGOOD G. 1996. Diagnosis and management of diseases of the diaphragm. Walthan Focus 6: 2-9.

HUNT GB AND JOHNSON KA. 2003. Diaphragmatic, pericardial, and hiatal hernia. In: Slatter D (Ed), Textbook 
of Small Animal Surgery. Philadelphia: Elsevier Science, p. 471-487.

IBEBUNJO C. 1993. Type, diameter and distribuition of fibres in some respiratory and abdominal muscles of the goat. Vet Res Commun 17: 171-182.

IGLESIAS LP, FAVARON PO, BORGHESI J, OLIVEIRA CARREIRA AC, MIGLINO MA AND DE MELO APF. 2017. Trend Toward Individualization of the Endocrine and Exocrine Portions of the Giant Anteater Pancreas (Myrmecophaga Tridactyla, Xenarthra). Anat Rec (Hoboken) 300(6): 1104-1113.

INTERNATIONAL COMMITTEE ON VETERINARY GROSS ANATOMICAL NOMENCLATURE. 2012. Nomina anatômica veterinária, $5^{\text {th }}$ ed., Knoxville, 160 p.

JOHNSON AK. 1998. Hérnia diafragmática, pericárdica e hiatal. In: Slatter D (Ed), Manual de cirurgia de pequenos animais, $2^{\mathrm{a}}$ ed., São Paulo: Manole, Cap. 37, p. 559-577.

JOHNSON NA. 1993. Diaphragmatic, pericardial, and hiatal hernia. In: Slatter D (Ed), Textbook of small animals surgery, $2^{\text {nd }}$ ed., Philadelphia: Saunders, p. 455-470.

JUNQUEIRA LC AND CARNEIRO J. 2004. Tecido muscular. In: Junqueira LC and Carneiro J (Eds), Histologia Básica, $10^{\mathrm{a}}$ ed., Rio de Janeiro: Guanabara Koogan, p. 184-205.

LESSA TB, DE ABREU DK, BERTASSOLI BM AND AMBRÓSIO CE. 2016. Diaphragm: A vital respiratory muscle in mammals. Ann Anat 205: 122-127.

LESSA TB, SILVA LCS, CONSTANTINO MVP, SANTOS PRS, ASSIS-NETO AC, BOMBONATO PP AND AMBOBRÓSIO CE. 2012. Morfologia comparativa do diafragma do sagui-de-tufo-branco e do sagui-de-carabranca. Biotemas 25: 119-124.

LEVINE SH. 1987. Diaphragmatic hernia: Small Airim Pract. Vet Clin North Amer 17(2): 411-430.

MACHADO GV AND SANTOS BS. 2008. Topografia do cone medular no tamanduá-mirim (Tamandua tetradactyla Linnaeus, 1758) (Xenarthra: myrmecophagidae). AVS 13(3): 172-175.

MARTINS CGG, DENARI SC AND MONTAGNINI AL. 2007. Comprometimento da Força Muscular Respiratória no Pós-Operatório de Cirurgia Abdominal em Pacientes Oncológicos. São Paulo. Arq Med ABC 32(Supl. 2): S2629.

MAZZANTI A, PIPPI NL, RAISER AG, GRAÇAS AFS, FARIA RX, ALVES AS, GONÇALVES GF, SELIDES R AND BRAGAS FA. 2001. Músculo diafragma homólogo conservado em solução supersaturada de açúcar para reparação de grande defeito no diafragma de cão. Cienc Rural 31: 277-283.

MOORE KL AND DALLEY AF. 2007. Anatomia orientada para a clínica, $5^{\text {a }}$ ed., Rio de Janeiro: Guanabara Koogan, $1101 \mathrm{p}$.

MOORE KL, DALLEY AF AND AGUR AMR. 2010. Clinically Oriented Anatomy, $6^{\text {th }}$ ed., Philadelphia: Lippincott Williams \& Wilkins, p. 1-1134.
MOREIRA PRR, GUIMARÃES GC, MACHADO MRF, SANTOS ALQ, GERBASI SHB AND MIGLINO MA. 2007. Ramificação e distribuição dos nervos frênicos no músculo diafragma do gato doméstico. Braz J Vet Res An Sci 44(4): 290-296.

POMPEU E, LIBERTI EA, OSAKA JT, RODRIGUES JR AJ AND TOLOSA EMC. 1992. The rabbit's diaphragm innervation. Revta Bras Ciênc Morfol 1: 33-36.

POPESKO P. 1990. Atlas de anatomia topográfica dos animais domésticos. São Paulo: Manole. v. III.

PUNCH PI AND SLATTER DH. 1985. Diaphragmatic hernias. In: Slatter DH (Ed), Textbook of small animal surgery. Philadelphia: Saunders, Cap. 59, p. 869-885.

RODARTE RRP. 2010. Tamandua tetradactyla-tamanduámirim. Bicho da Vez, Museu de Zoologia João Moojen.

ROMMEL S AND REYNOLDS JE. 2000. Diaphragm structure and function in the Florida Manatee (Trichechus manatus latirostris). Anat Rec 259: 41-51.

SALONEN V, LEHTO M, KALIMO H AND PENTTINEN RAH. 1985. Changes in intramuscular collagen and fibronectin in denervation atrophy. Muscle Nerve 8: 125-131.

SAYEED RA AND DARLING GE. 2007. Surface anatomy and surface landmarks for thoracic surgery. Thorac Surg Clin 17: 449-461.

SHAFFER JD. 1964. Prothesis for agenesis of the diaphragm. 7. Amer Med Ass 188: 1000-1002.

SKANDALAKIS J. 2004. Diaphragm. Surgical Anatomy: The Embryologic and Anatomic Basis of Modern Surgery. Athens: Paschalidis Medical Publications 1: 353-392.

VANDERVOORT A. 1998. Alterações Biológicas e Fisiológicas. In: Pickles B, Compton A, Colt C, Simpson $\mathrm{J}$ and Vandervoort A (Eds), Fisioterapia na Terceira Idade. São Paulo: Santos, p. 67-79.

WARKANY J AND ROTH CB. 1948. Congenital malformations induced in rats by maternal vitamin $A$ deficiency. J Nutr 35: 1-4.

WILSON GP AND HAYES JÚNIOR HM. 1986. Diaphragmatic hernia in the dog and cat: a 25 -year overview. Semin Vet Med Surg 1: 318-326.

WILSON GP, NEWTON CD AND BURT JK. 1971. A review of 116 diaphragmatic hernias in dogs and cats. J Amer Vet Med Assoc 159(9): 1142-1145.

WYNN J, ASPELUND G, ZYGMUNT A, STOLAR CJH AND MYCHALISKA G. 2013. Developmental outcomes of children with congenital diaphragmatic hernia: A multicenter prospective study. J Pediatr Surg 48(10): 1995 2004.

ZIFAN A, KUMAR D, CHENG LK AND MITTAL RK. 2017. Three-Dimensional Myoarchitecture of the Lower Esophageal Sphincter and Esophageal Hiatus Using Optical Sectioning Microscopy. Sci Rep 13(7): 13188. 